\title{
Contributions towards a Knowledge of the Anatomy of the Genus Selaginella.
}

\author{
The Root.
}

\author{
BY \\ J. C. TH. UPHOF, Ph.D. \\ With thirteen Figures in the Text.
}

THE author wishes to make an attempt to give an account of the 1 anatomy of the root of the genus of Selaginella, under which he includes also the so-called rhizophores. In various excellent articles in 'Annals of Botany', the anatomy of the stem, leaf, and ligule of this genus have been studied by Gibson, and the strobilus by Miss Mitchell. This leaves the root of the genus untouched. The writer has made his observations at the Royal Botanical Gardens at Kew, where most of his studies have been done at the Jodrell Laboratory, and is therefore thankful for the kind help he received from Sir David Prain, Director of the Botanical Gardens, and from Mr. L. A. Boodle, Curator of the Jodrell Laboratory; also to $\mathrm{Mr}$. W. Emery for preparing the manuscript for publication.

The present species of the genus of Selaginella need some consideration ; the author considers them as remnants of older periods (they existed already in the Palaeozoic Flora) in which related genera reached their highest pitch of development. The origin and morphological development of their organs will be still better understood when fossil forms have been properly studied, which no doubt will be the case in the near future. It has to be considered that Selaginellas and the present living related families are the most primitive forms of vascular plants, and therefore morphologically of the utmost importance. Especially in the fossil species and monstrosities of plants of present forms there may be some likelihood of studying the morphological origin of one of the most important organs of the higher plants, namely, that of the root.

The present living distant relatives of the Selaginellas are the Lycopodiaceae and Psilotaceae; the former are in possession of true roots, whose anatomical construction is much like that of the stem; on the other hand, the latter family has no true roots, but as a substitute has subterranean shoots. The genus Isoetes, which is at present the only representative of

[Annals of Botany, Vol. XXXIV. No. CXXXVI. October, 1920.] 


\section{Uphof.-Contributions towards a Knowledge of}

the family of the Isoetaceae, also shows in some of its characteristics slight resemblance to Selaginella, and possesses true roots. Under the fossil forms, Stigmaria has been extensively studied; especially Scott (11) has greatly distinguished himself; he considers the subterranean organs of this genus as a primitive stage in the differentiation of root and shoot.

The aerial roots of Selaginellas have been considered by various investigators as leafless shoots, as roots, and as organs standing between root and shoot; others consider them as special organs (1).

The first investigators who have drawn considerable attention to the aerial roots are Leitgeb (8) and Nägeli, who call them Wurzelträger (= rhizophores) and consider them morphologically as stem-like, leafless organs, which only perform the function of bearing true roots; both investigators consider it as of much importance that the rhizophores have no root-cap and therefore could not be roots; on the other hand, there are nevertheless roots, whose morphological significance is beyond doubt, which do not develop any such root-caps, as has been studied under the Hippocastanaceae and Sapindaceae by Waage (15). Also Pfeffer (9), Treub (14), Bruchmann (2), Fries (5), Campbell (3), and Worsdell (17) consider them as leafless stems. On the other hand, van Tieghem (12), Douliot (13), and Sarauw (10) suggest they are roots; whereas Goebel ( 6 and 7 ) supposes they have the characteristics of both; also Bower (1) states that the structure is like that of a root, but that in some cases the rhizophore has a structure resembling that of an axis. Those who are in favour of a stem-like nature, such as Pfeffer (9), Bruchmann (2), and Worsdell (17), claim that sometimes leafy shoots are seen instead of leafless rhizophores, although on the other hand it has been observed that true roots may give rise to branches, as in Anthurium longifolium, Asplenium esculentum, and Neottia Nidus-avis (16).

Generally the root of the genus Selaginella is simple in construction and differs from the stem. Although there is much discussion as to the morphological value of the rhizophore, as has been shortly outlined above, the writer does not hesitate to consider them as roots which have been developed in the air instead of in the soil, and have therefore had to adapt themselves to their particular environment, which necessitated a change in some of the tissues. Instead of being called rhizophores, the name 'airroots' would therefore be more appropriate; this name will be frequently used in this sense in the present article.

Both kinds of roots have been examined by the author in 262 different species, of which about forty have been studied anatomically.

There is very little prospect of arranging this genus phylogenetically in accordance with the appearance of the roots. The aerial roots are always exogenous in origin, whereas the branching of the roots in the soil is monopodial, although apparently dichotomous. There is apparently more diver- 
sity in the location of the roots of the air than those developed in the soil. The former have their origin always at the forking off of an ordinary branch, either at the upper or lower side of the stem; they may be found over the entire length of the stem, e.g. S. Kraussiana, S. Bakeriana, and S. serpens; in other species they are only seen below the middle of the stem, as in 5. atrovirens and S. viticulosa. Xerophytic species such as S. cuspidata,

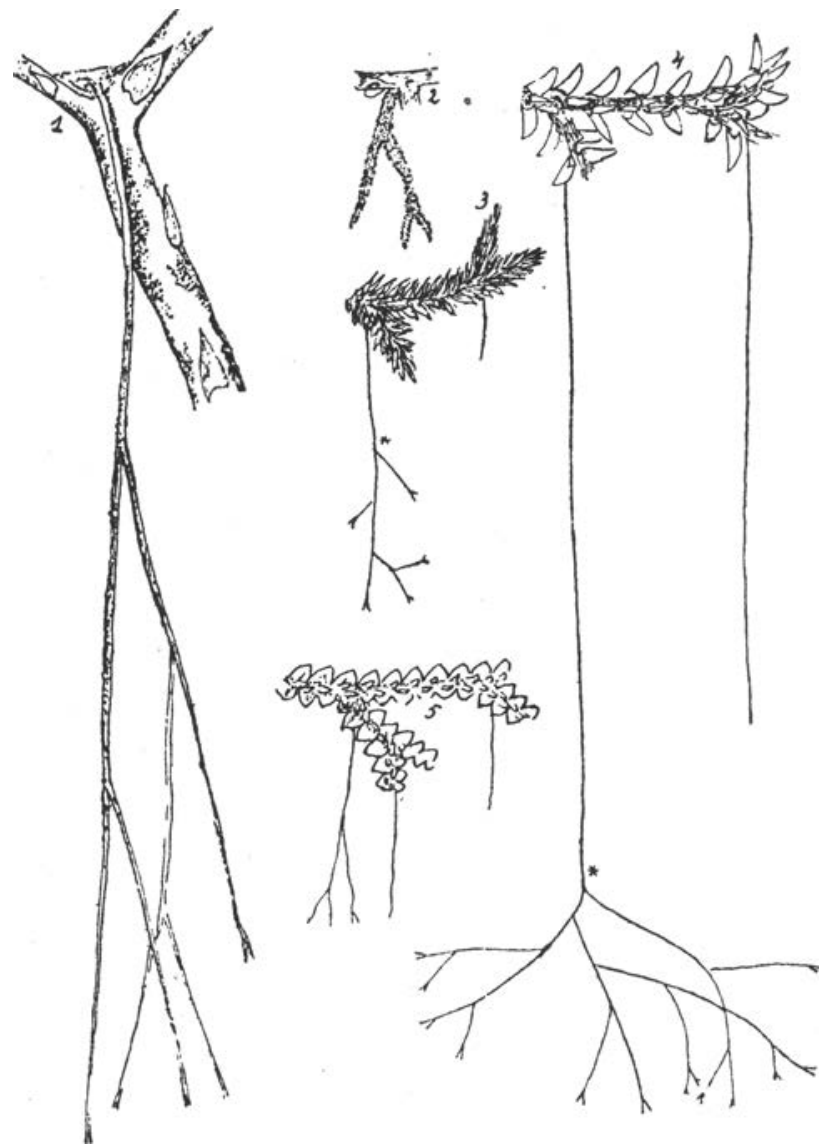

FIG. I. Different types of rhizophores or aerial roots. I, S. Wildenozvi; 2, S. pilifera; 3 , S. rupestris; 4, S. rubella; 5 , S. serpens.

S. pilifera, and S. lepidophylla, only form aerial roots towards the base of the stem when they are grown in a very moist environment, which also may be said of the hygrophytes, S. Vogelii, S. caulescens, and S. viridangula. On the other hand, the xerophytic species, $S$. sangzinolenta, forms under natural conditions aerial roots at several places of the entire stem.

The thickness of the aerial roots, which differs but slightly in the same species, is fibre-like (about $\frac{1}{4} \mathrm{~mm}$. in thickness) in $S$. molliceps, S. Bakeriana, $S$. apus, and $S$. haematodes; they are string-like (about $\mathrm{I} \mathrm{mm}$. and more in 
thickness) in S. rubella, S. Martensi, and S. decora; while those of $S$. Wildenowi are as thick as $2.5 \mathrm{~mm}$. and sometimes slightly more in diameter.

The air-root of some species practically never branches before entering the soil, e.g. S. uncinata, S. rubella, S. formosa, and other species; on the other hand, those of other species may branch when in the air, e.g. S. Wildenowi, S. rupestris, S. rupincola, and S. inaequalifolia.

The length of the rootlets and entire root system in the soil depends greatly upon the presence of plant food, and also stands in close relation to the size of the air-roots, whose length may be considerable in some species, as is summarized in the following list:

\begin{tabular}{|c|c|c|c|c|c|}
\hline Name of Plant. & $\begin{array}{c}\text { Length. } \\
\text { mm. }\end{array}$ & $\begin{array}{c}\text { Diam. } \\
\text { mm. }\end{array}$ & Name of Plant. & $\begin{array}{c}\text { Length. } \\
m m .\end{array}$ & $\begin{array}{r}\text { Diam. } \\
m m .\end{array}$ \\
\hline S. molliceps & $6-15$ & & S. Bakeriana & $6-12$ & \\
\hline S. patula & $10-18$ & & S. uncinata & $35-40$ & \\
\hline S. decora & $30-45$ & $\frac{3}{4}-I$ & S. inaegralifolia & $20-40$ & \\
\hline S. viticulosa & $3^{-8}$ & & S. Kraussiana & $25-35$ & \\
\hline S. Wildenowi & $9^{0-260}$ & $1-2 \frac{1}{2}$ & S. apus & $5-12$ & \\
\hline S. cuspidata & $5-8$ & $I-1 \frac{1}{2}$ & S. Douglasi & $20-28$ & \\
\hline S. pilifera & $5-8$ & $\frac{3}{4}-1 \frac{1}{2}$ & S. grandis & $8-12(20)$ & \\
\hline S. rupestris & $4-8$ & 1 & S. Galeotti & $80-120$ & \\
\hline S. serpens & $6-12$ & & S. formosa & $40-60$ & \\
\hline S. Martensi & $30-60$ & $\frac{3}{4}-1$ & S. haematodes & $6-15$ & \\
\hline S. rubella & $30-65$ & $\frac{3}{4}-\mathbf{I}$ & S. sanguinolenta & $\cdot 4^{-8}$ & \\
\hline
\end{tabular}

Anatomically there is a marked difference between the air-roots and terrestrial roots on one hand, and the stem (especially of the heterophyllous species) on the other hand. Of the species whose anatomical construction is described below many sections of roots in various stages of development have been made, but no lacunae and no trabeculae, which are characteristic in stems of all heterophyllous species, have ever been, encountered, and these sections show a very important differentiation as far as the anatomy is concerned. For this purpose longitudinal sections of air-roots with attachment of the stem were made by the writer from several species. Fig. IV, I, shows such a section of $S$. rubella, in which the difference between the two vascular bundles of both kinds of plant organs is clearly visible; the bundle of the stem is above, that belonging to the air-root being on the left of the drawing. There are, however, according to some investigators, indications of the transformation of such aerial roots into leafy shoots, which would apparently prove that these organs are no real roots but shoots. Bruchmann (2) has observed in S. Kraussiana that when individuals which have been outside during the summer are in autumn put into a warmer environment these roots form at the apex stems with small leaves, as has been stated above; also that other plants of other families may form leafy branches at their roots. Also Pfeffer (9), and later Worsdell (17), have 
made observations that, instead of so-called rhizophores, which had been expected, they found small-leaved shoots in their place, thus apparently proving that rhizophores are of stem-like origin. No author, however, seems to have made a comparative anatomical and physiological study of such leafy shoots and rhizophores or aerial roots.

In S. uncinata I have frequently observed true (although thin and small) twigs instead of roots or so-called rhizophores. These twigs bear small leaves in proportion to their size. The leaves are always at some distance from each other, such shoots having thus the appearance of the main stems. In one instance I noticed that such an organ was deprived of its leaves on a length of about $\mathrm{I} 2 \mathrm{~mm}$., which is rather considerable for such a thin shoot, the remaining part being further covered with leaves as described above. Such shoots branch in the usual way, producing at the proper places aerial roots. Without any further anatomical study one would be apt to suppose that the leafless part would have the construction of a rhizophore and the leafy part that of a stem. Such modifications, however, we only observe where normal twigs have been damaged or bruised in some way or other. Often it could be observed in S. uncinata (Fig. II, I, A), and the writer noted it a few times in S. grandis (Fig. III, 5), S. inaequalifolia, S. Wildenowi, S. Kraussiana, S. serpens, and once in S. rubella, S. Bakeriana, and S. Douglasi.

The anatomical construction of such shoots is exactly the same as that of the ordinary stem. The lacunae and trabeculae, which are never formed in the aerial roots, are present in the shoots as mentioned above, although smaller, in proportion to their size, than those in the larger stems. That part of the shoot which is leafless for a distance of $12 \mathrm{~mm}$. also contains lacunae, and consequently some trabeculae, and is a long internode. Moreover, I observed in all cases that such a long internode is already positively heliotropic in its early youth, whereas the aerial root is negatively heliotropic from its start. For a further comparison, the following drawings in Fig. II relating to S. uncinata are useful. I is an old shoot which has been bruised, and soon formed two little twigs, $A, \mathrm{~A}^{1}$, which according to some investigators are rhizophores transformed into leafy branches; $A^{1}$ has formed in the usual way one aerial root, B; 2 is a section of the so-called metamorphosed rhizophore which has, as stated above, the same construction as an ordinary stem, although the trabeculae are somewhat shorter; also the further part of the vascular bundle is the same as that of a stem ; 3 is a part of the main stem, drawn for comparison; 4 is a cross-section of aerial root $\mathbf{B}$; 5 is the epidermis and hypodermis of an ordinary aerial root, and 6 that of rhizophore $\mathrm{B} ; 7$ is a cross-section of an ordinary young aerial root, 8 of a root developed in the soil, 9 and 10 the epidermis of a stem and of an aerial root; and II shows the branching system of a root, entering the soil at $*$. 
An intermediate, as far as anatomical construction is concerned, between rhizophore and stem has not been observed, although the writer studied thirty-five such so-called transformed rhizophores of different species. Moreover, they are all distinctly positively heliotropic from the very start, while on the contrary all rhizophores or aerial roots, as has been stated, are

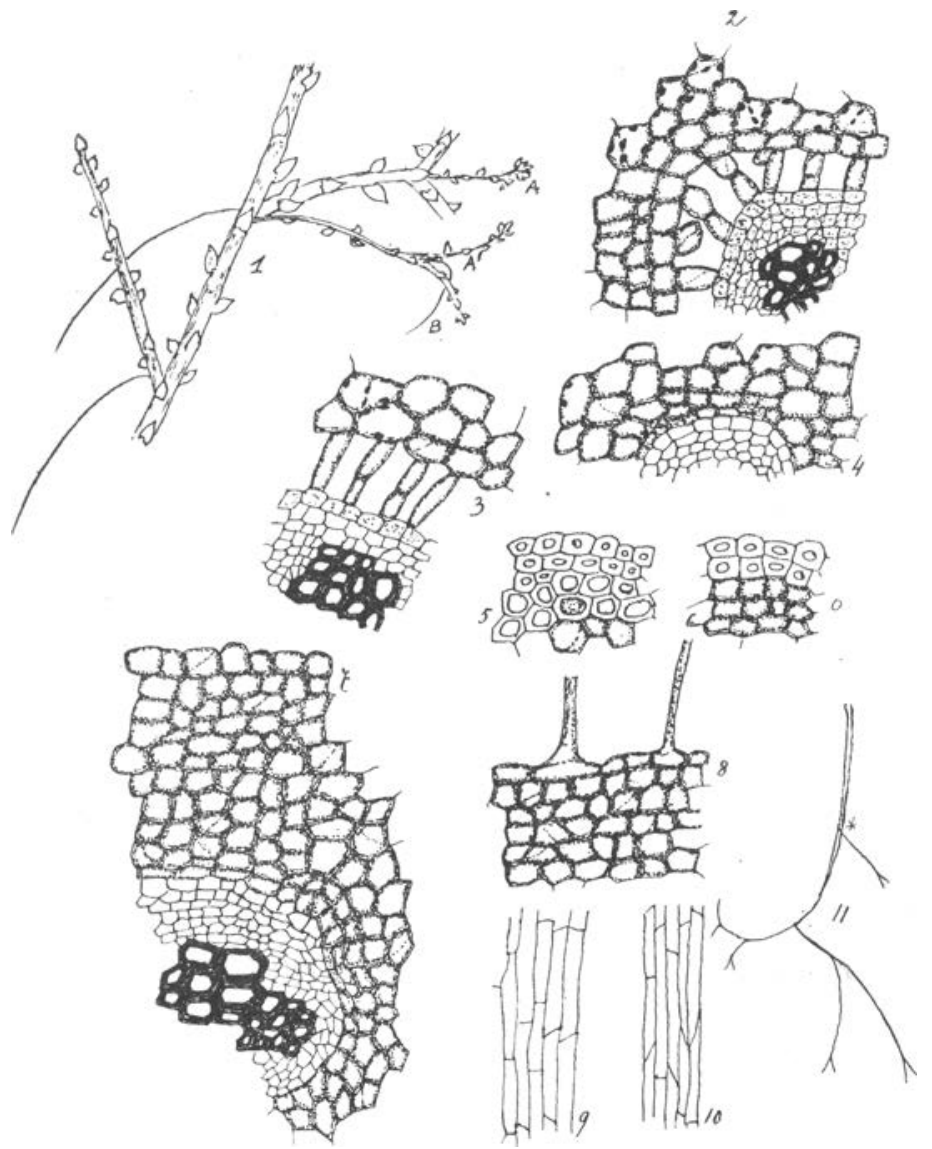

FIG. 1I. I, stem of S. uncinata : A, branches instead of rhizophores; B, rhizophore formed by such a branch ; 2 , cross-section of stem $A$ in $I ; 3$, cross-section of ordinary stem ; 4, cross-section of rhizophore $\mathrm{B}$ in $\mathrm{I} ; 5$, epidermis and hypodermis of ordinary rhizophore; 6 , the same of rhizophore $\mathrm{B}$ in $\mathrm{I} ; 7$, cross-section of young rhizophore; 8 , cross-section of a young root with root-hairs ; 9 , epidermis of stem; 10, the same of rhizophore; 11 , branching system.

negatively heliotropic, an argument in favour of their root nature which is beyond doubt.

The same indications are shown in Fig. III, 3-8, in Selaginella grandis, which are even more characteristic than in S. uncinata; as the stem of the former has a strongly developed system of vascular bundles which manifests itself also in the small shoot, whereas the rhizophore and root have a small 
vascular bundle of which the xylem consists of only eight to nine tracheides having only one protoxylem.

The negative heliotropism of both types of roots has been studied in

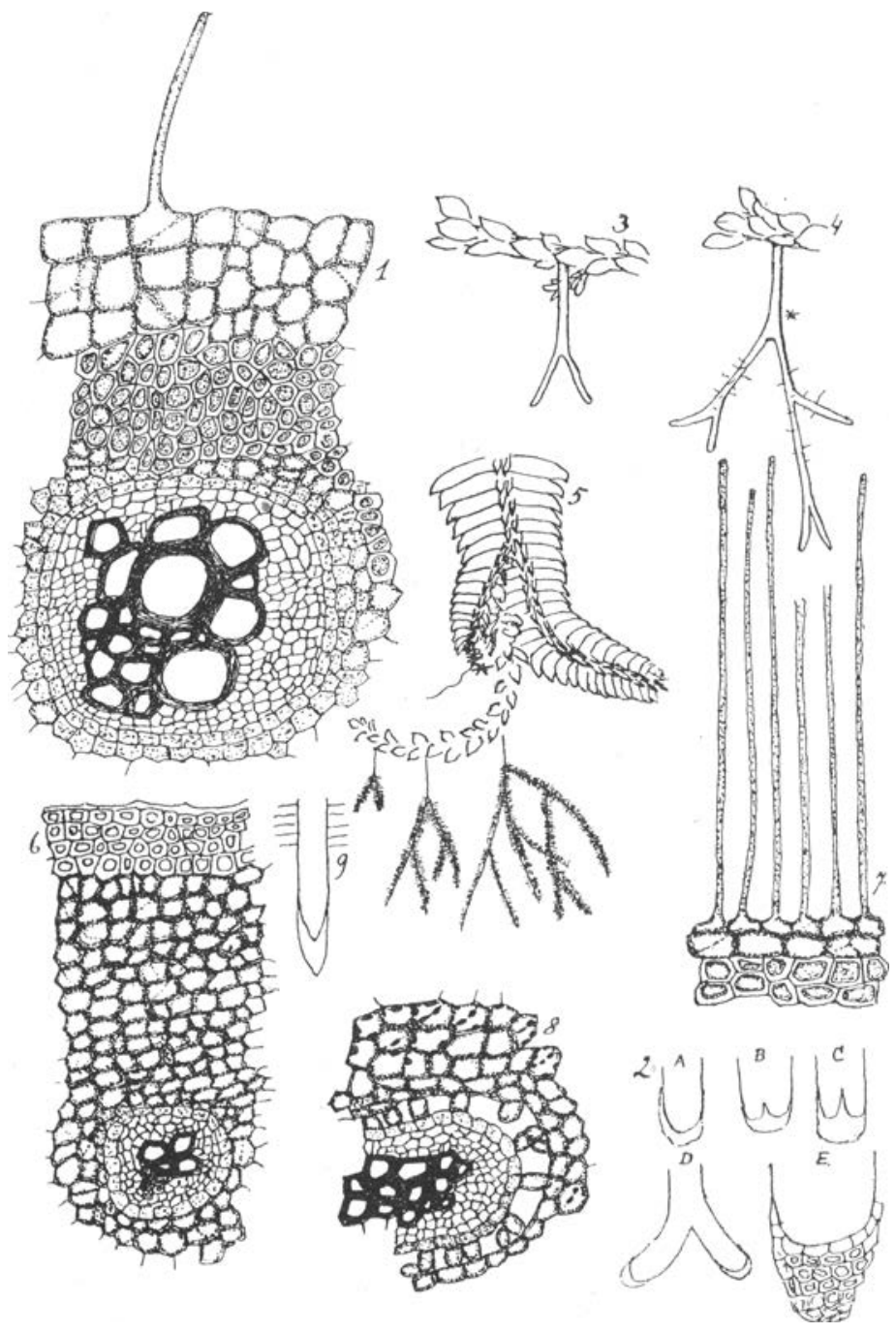

Fig. III. I, c1oss-section of root of S. IVildenowi; $2(\mathrm{~A}-\mathbf{E})$, development of root of same species; 3-9, S. grandis; 3 , aerial root without root-hairs or root-cap; 4 , aerial root from * downward with root-hairs and root-cap; 5 , branch developed in extreme moisture, * branch instead of rhizophore, which has formed an aerial root; 6 , cross-section of rhizophore; 7 , part of rhizophore with root-hairs; 8 , cross-section of branch which is in the place of rhizophore; 9, root with root-cap and root-hairs.

S. Kraussiana, S. Wildenowi, S. rubella, S. molliceps, S. pallida, S. serpens, and $S$. inaequalifolia. Young shoots of these species were turned upsidedown; the very young aerial roots soon turned in the opposite direction to 
that of the incident light; when the darkest part was on the left of the stem, the aerial roots turned themselves in this direction; on the other hand, the true shoots always tend to grow positively heliotropic. Of old or partly full-grown rhizophores, the growing-point always develops towards the darkest side again after having been moved.

Diversified directions of various aerial roots can be readily observed on strongly branching Selaginellas, which grow intermingled with other densely growing plants and thus do not get an equal distribution of light. On such plants one finds these roots growing in all directions from vertical to horizontal, according to the effectiveness of the entering light.

Plants which were grown in hanging baskets in a light part of a greenhouse show in their rhizophores various degrees of sensitiveness to light. Rhizophores or aerial roots which are hanging from the stem between the glass of the greenhouse and the basket in which the plant grows are strongly curved towards the basket; on the other side, where the light is less intense on account of the presence of other plants, the "curvature of these aerial roots is less marked; thus the degree of the sensitiveness is not so pronounced, and consequently the rhizophores are less curved in the direction opposite to the light. The above facts were observed by the author with S. uncinata, S. Lobbi, S. Watsoniana, and S. Martensi. In a practically similar way the negative heliotropism was demonstrated by putting parts of stems with young rhizophores of S. grandis, S. serpens, S. haematodes, and $S$. Bakeriana in watch-glasses which were covered with a glass plate with black paper above it except for a narrow margin towards the window side of the laboratory in which they were placed. The top of the rhizophore or aerial root was placed in such a way that it was touched by the light. After eight days the apex of these rhizophores had all partly developed in the opposite direction to that of the incident light, whereas the young shoots were growing towards the light.

- When aerial roots enter the ground, their one-sided growth is not as strongly marked as if they were growing in the air, as the opposition of the light is overcome as soon as they enter the soil. Their growth is more or less spreading in all directions, depending only upon the moisture and the presence of plant food in the substrata. In the soil they branch monopodially in the same way as they would do in the air.

Aerial roots which are exposed to the light contain in their cells a considerable amount of chloroplasts, which are absent in the roots growing in the soil ; such organs of S. Wildenowi, S. rubella, and S. Lobbi, which were afterwards exposed to the light, became greenish and developed chloroplasts, especially in the cortex.

Some anatomical difference exists between the aerial root and the terrestrial root; the former, on account of its environment, is surrounded by a thick-walled epidermis and hypodermis, and sometimes one or two layers of 
the outer cortex are thick-walled, which is caused by secondary layers in the cell-walls. Treatment with potassium hydroxide gives a yellow colour and suggests the presence of suberin; its amount depends upon the exposure; organs developed in a moist and shady climate contain considerably less suberin than those grown in a dry exposed place.

Rhizophores or aerial roots which approach the soil become even more thin-walled, and having touched the soil the cell-walls are only composed of their primary walls. Such roots, soon after entering the soil, form root-hairs. Such behaviour was studied by the writer on S. Lobbi, S. rubella, S. Wildenowi, S. Kraussiana, S. Donglasi, and S. Martensi. Of the latter species, the following observations may be made: The acrial root has a small-

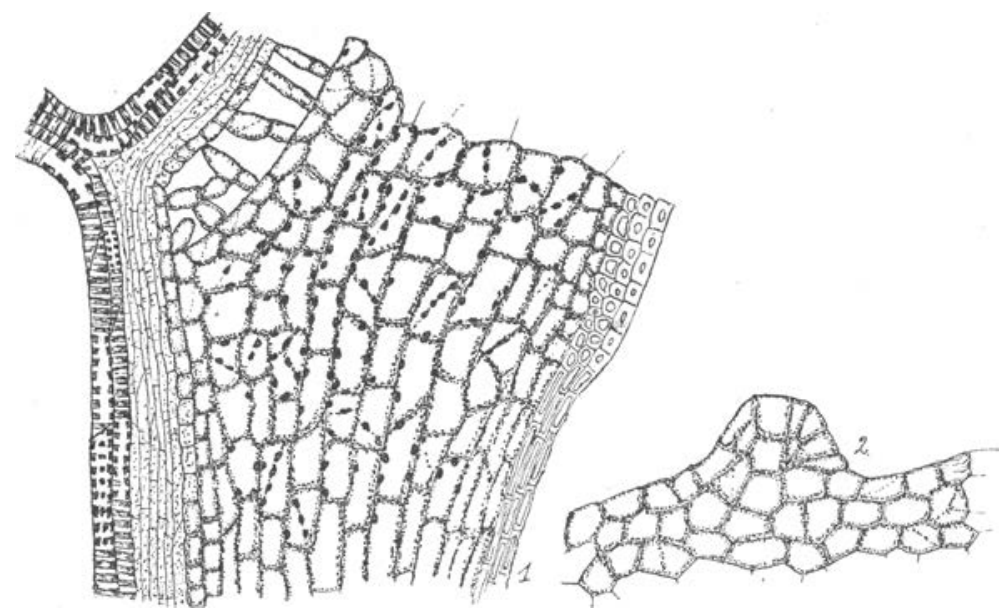

FIG. IV. S. rubella. I, junction of vascular bundles of rhizophore and stem ; 2, young rhizophore.

celled and rather thick-walled epidermis; the cells of the hypodermis are also thick-walled; the outer rows of the cortex show some secondary thickening of their walls, and in very exposed places these cell-walls of the cortex may be considerably thicker (Fig. V, 3). When the aerial root approaches the moist soil, at a distance of about 2 millimetres, its structure soon shows some differences, e.g. the epidermis is not as thick-walled, and the space in the cells is larger; further, there is no great difference in size between the cells of the epidermis and of the hypodermis (Fig. V, 4), such difference as exists having no doubt been caused by the moisture of the soil ; there is, however, no difference in the cells of the cortex, whether developed in the air or near the surface of the soil. When the aerial root actually touches the soil the epidermis does not show any secondary layers in its walls, although they are still present in those of the hypodermis; the epidermis, however, is often followed by another, sometimes two layers of 
cells which are thin-walled, and which the author considers to have originated from the epidermic cells, as when very young these cells lie in radial direction towards one another. Sometimes it happens that the epidermis of such a root has formed a few root-hairs; -but after having penetrated the soil the root-hairs are abundantly formed, not, however, from every epidermic cell, e. g. in the case of S. lepidophylla or S.pilifera.
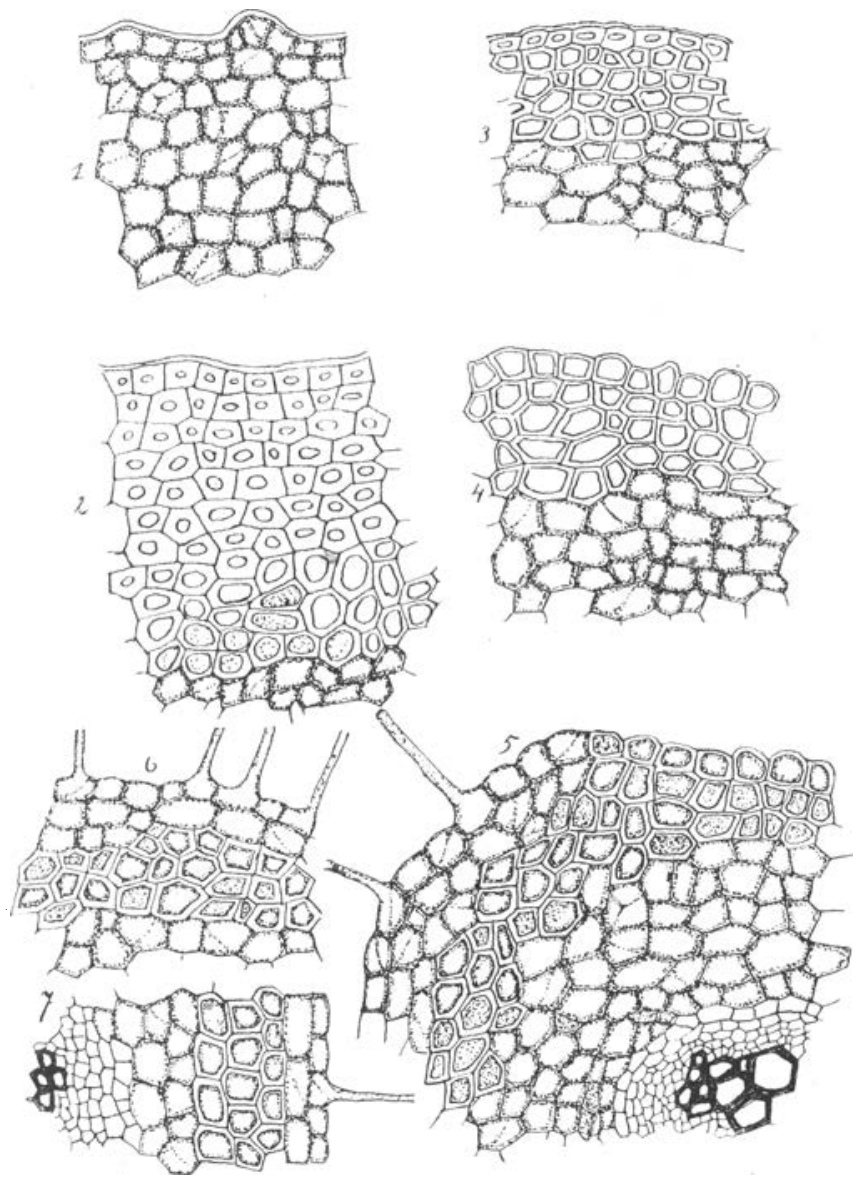

FIG. V. 1, 2, S. Bakeriana: 1, part of young rhizophore; 2, old rhizophore. 3-7, S. Martensi; 3 , rhizophore surrounded by air; 4, rhizophore approaching the soil ; 5 , rhizophore touching the soil, showing habit of aerial root and terrestrial root ; 6,7 , root developed in the soil.

Anatomically and physiologically interesting was the following experiment. Growing rhizophores, which were 3 to Io millimetres distant from the soil, were covered lengthwise for one half with wet soil, the other side being exposed to the air; after ten days the latter part had a construction like a root developed in the air, while that part which was grown against the soil had the same appearance as a terrestrial root, e.g. thin epidermis 
walls with root-hairs followed by another thin-walled layer and then by a three-layered hypodermis composed of somewhat thick walls, before one observes the cortex proper, this being the regular succession of tissues found in practically all roots with which the writer has worked. Near the boundary where the rhizophore partly touches the wet soil and partly the free atmosphere, one is able to find any modification between the aerial and terrestrial root, due to the direct action of environment. Both types can be observed in Fig. $V, 5-7$.

The writer suggested above that the thin-walled layers of a terrestrial root which underlie the epidermis have been formed from the latter, whereas the somewhat thick-walled layers belong to the hypodermis. Such can clearly be observed on $S$. viticulosa, the aerial roots of which have a redcoloured epidermis and hypodermis, the colour pigment being encrusted in the secondary walls. The same colour can be observed in the thick-walled layers of the terrestrial root, although its colour is not present in the thin walls of the epidermis cells, on account of the absence of secondary layers. Moreover, a longitudinal section of an aerial with a terrestrial root shows the connexion of the hypodermis in both. The author is unable to understand why these cells of hypodermis are thick-walled in a terrestrial root.

In twenty-two instances roots of $S$. rubella were grown in the soil and, still being connected with the plant, were carefully taken out of the soil, washed off, and kept so that they were unable to touch the soil; some of these rapidly died; in two instances the roots continued their growth in the air, their root-caps gradually consisting of less cells and finally disappearing; at last this part of the root became in construction again entirely an aerial root.

The above anatomical and physiological investigations are not in favour of the stem habit of the rhizophores, which are on the contrary entirely root-like in construction and behaviour. In one of the above-mentioned experiments it could not be stated that the half of the rhizophore which was open to the air was a stem, while the half which was surrounded by soil was a root.

All roots possess a monarch vascular bundle, the endodermis of which is in some species difficult to distinguish; it is very clear in S. Wildenowi and S. rubella, but does not show very well in S. serpens, S. Bakeriana, and some other species. No root, whether grown in the air or in the soil, ever develops any lacunae or trabeculae. The pericycle is composed of one layer. The elements of the phloem, although not as abundant as in the vascular bundle of a stem, are arranged in the same manner as in the stem, and can to a certain extent be compared with the studies of Gibson on the anatomy of the stem. The sieve-tubes are consequently present, although apparently not much developed near the protoxylem. The phloem surrounds the xylem entirely. This xylem possesses but one group of proto- 
xylem (the vascular bundles of a stem have more), and is strongest developed in the oldest part of the aerial root of S. Wildenowi. The tracheides of the metaxylem differ greatly in number in the various species; they are abundant in $S$. Wildenozi and $S$. mubella, while only a few are to be found in S. serpens. The types of tracheides are the same as in the stem.

The author observed that a root-cap is present on all roots which are in possession of root-hairs, whether these roots have been developed in the air or in the soil. On the other hand, roots which do not have such roothairs, as is the case with the so-called rhizophores, are correlated with the absence of a root-cap. As the writer demonstrated, some species may. lose the root-cap when terrestrial roots are forced to develop in the air; on the other hand, the author was unable to force plants which develop roots with root-hairs and root-cap in the air, such as $S$. grandis, to form in some way or other roots without root-hairs or root-cap; although $S$. grandis may form in a dry environment aerial roots without root-hairs.

The root-cap and root-tip are very simple in construction, and the development has already been studied by Treub (14), van Tieghem (13), and other investigators. The root-cap is pointed in $S$. grandis; in S. Bakeriana, S. rubella, and S: Wildenowi it is rounded, and is especially well developed in the latter species. In homophyllous species, e.g. S. rupestris, S. rupicola, and $S$. densa, it is least developed and is composed of but a few cells.

Before giving a description of the anatomy of roots of various species of Selaginella the author wishes to state that he has made no study of this organ in the young sporophyte. An account of the development and comparative study of the latter will be given in another publication.

\section{Selaginella Wildenowi.}

The aerial roots or rhizophores are in this species strongest developed of all (Fig. I, I). They attain a length of 90 to 260 millimetres, the diameter ranging from $I$ to about 2.5 millimetres. They are red in colour, the pigment being dissolved in the vacuoles of the cells, especially those of the hypodermis and cortex. They may be developed at any distance up the plant.

The epidermis is composed of smaller cells than the hypodermis and soon becomes thickened by secondary layers. The hypodermis is composed of three to four layers of cells. The following cells of the cortex are considerably larger than those of the former tissues, and are thin-walled and usually composed of twenty to twenty-five rows of cells in the old rhizophores or about fifteen to twenty rows in those of the first branching (Fig. VI, I-5, and Fig. VII). The endodermis is well developed in the main rhizophore, the cell-walls in young specimens showing a varying degree of 
thickness in which suberin can be demonstrated. The protoxylem is highly developed in the oldest part of the rhizophore, before it branches off for the first time; it is composed of from twenty-five to even forty tracheides; in young organs the secondary thickening of the walls takes place at the outer side of this group of tracheides, as is shown in Fig. VII ;

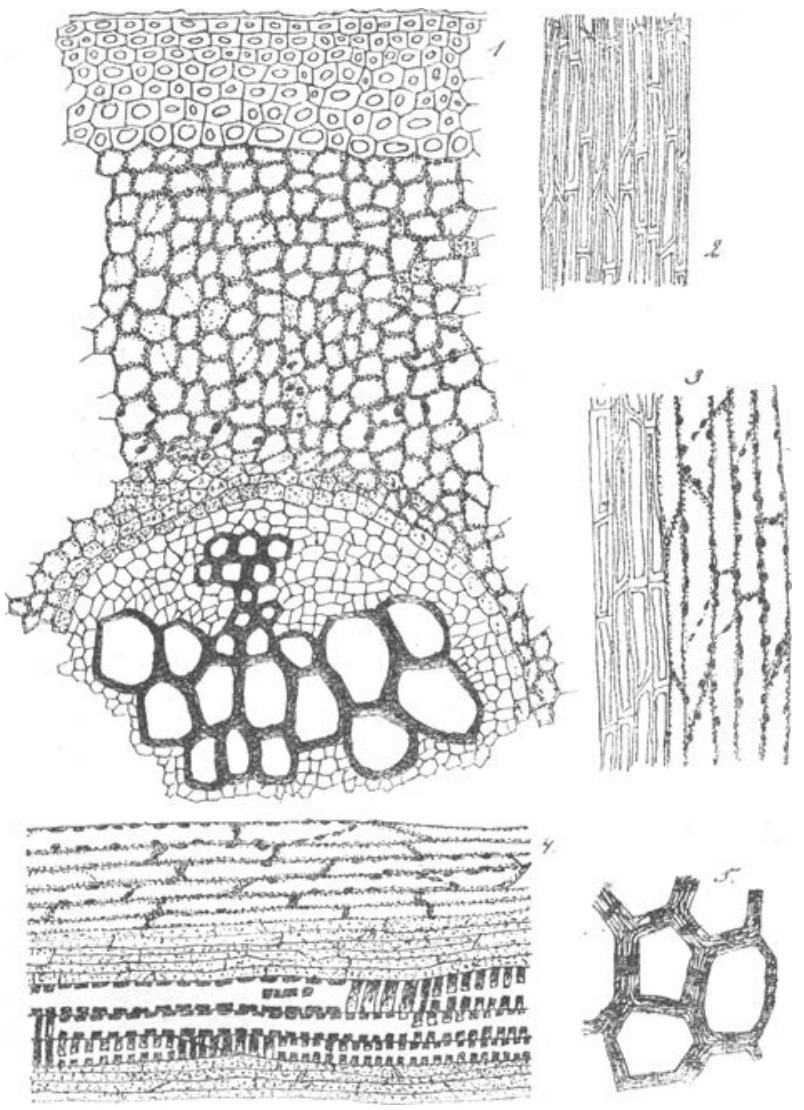

Fig. VI. S. Wildenowi. I, cross-section of rhizophore ; 2 , longitudinal section of epidermis and hypodermis; 3 , longitudinal section of thick- and thin-walled cortex; 4, longitudinal section of cortex, endodermis, pericycle, protophloem, phloem, parenchyma, and metaxylem; 5 , cross-section of tracheides of xylem.

when the rhizophore has branched off the protoxylem usually consists of six to ten tracheides. The metaxylem is always strongly developed, especially in the old primary rhizophore; its tracheides are broad. The entire vascular bundle of the primary rhizophore is kidney-shaped (Fig. VII); when this organ has branched off the bundle is roundish (Fig. VI, I).

The terrestrial root possesses an epidermis with large cells which accasionally lengthen towards the periphery into root-hairs; the epidermis 
is followed by two layers of thin-walled cells which are of the same appearance. The next tissue met with is the hypodermis, which is composed of about three to five layers of cells; the walls are thick on account of the presence of secondary walls. The cortex is thin-walled, though sometimes its outer cell-layer may be slightly thick-walled. The endodermis is not as

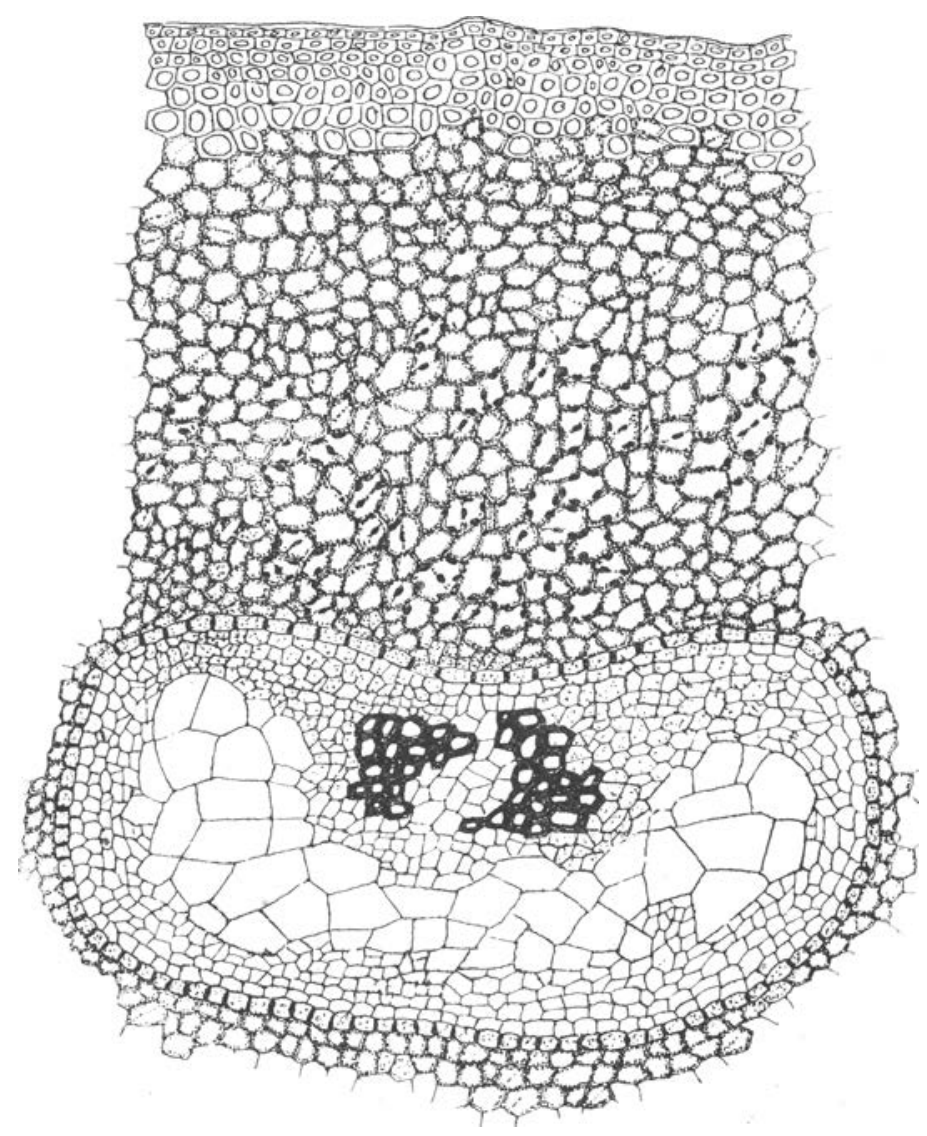

FIG. VII. Section of the top part of a young rhizophore of S. Wildenozi.

easily visible as that of the primary air-root or rhizophore. The phloem contains but few sieve-tubes in comparison with the aerial root. The xylem is the same as has been described above.

\section{Selaginella rubella.}

The aerial root reaches a length of 30 to 65 millimetres and a diameter of $\frac{3}{4}$ to I millimetre. The epidermis has rather a thick-walled cuticle, and the other walls of the epidermis and hypodermis are thick, those of the former differing but slightly in size from those of the latter, except that 
hypodermis cells belonging to the inner row are sometimes larger. The outer layer of the cortex also may be slightly thick-walled, although the remainder are thin-walled, and are composed of eight to ten rows of cells. The cells of the endodermis are much smaller than those of the inner cortex, and therefore easily visible. The phloem is much like that of the stem, and therefore does not need any further description. The xylem is composed of

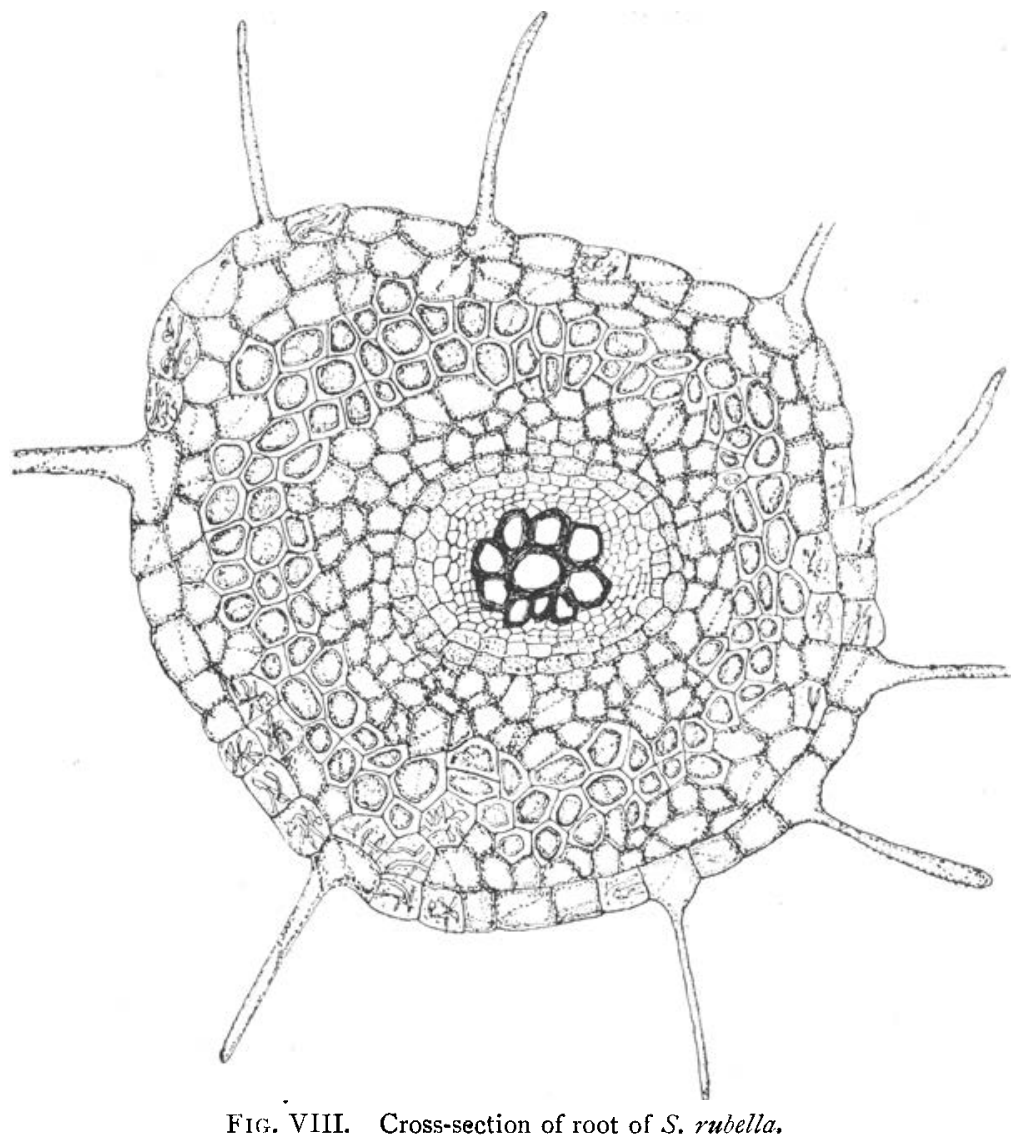

thirty-two to forty tracheides; the members of the protoxylem, although visible, are not much smaller than those of the metaxylem.

All cells contain a red pigment which is dissolved in the vacuole. The cells of the hypodermis, cortex, and sometimes of the epidermis contain mycelia, which suggests the presence of mycorrhiza (Fig. IX, I and 2). No further study of this mycorrhiza has been made, as it would require a special treatise.

The terrestrial root (Fig. VIII) has a large-celled epidermis, and cells of the two following layers also have the same appearance. The hypodermis 
is composed of three rows of cells, which are slightly thick-walled through secondary layers; the thin-walled cortex is composed of three to four layers. Of the vascular bundle the phlocm is in comparison stronger.developed than the xylem; the latter is composed of eight to ten tracheides, of which

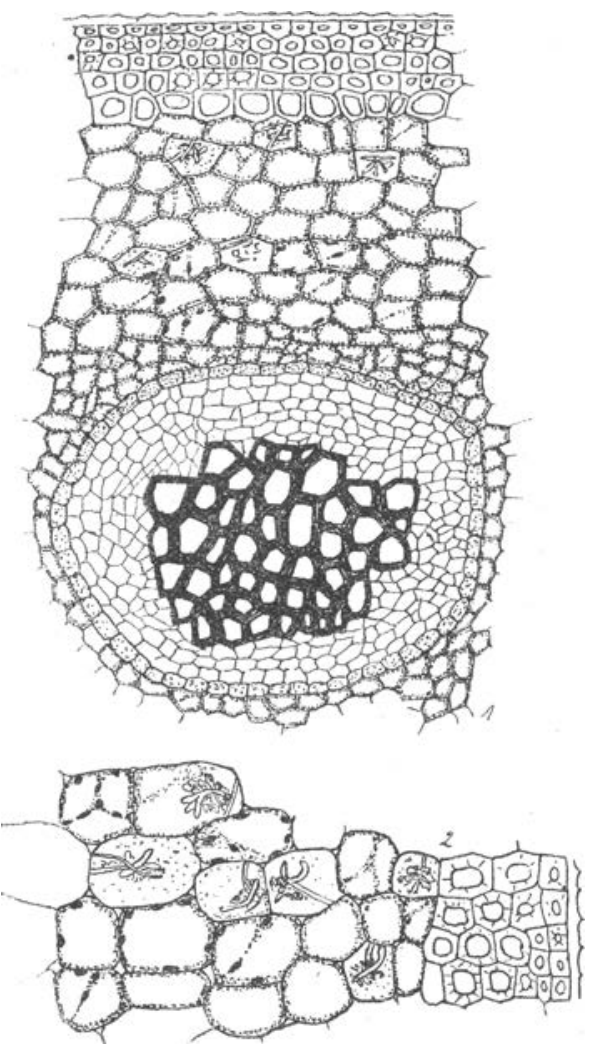

FIG. IX. S. mbella. I, cross-section of rhizophore; 2, longitudinal section : some cells show mycorrhiza.

about three to four belong to the protoxylem. Also in the root mycelia have been found.

\section{Selaginella haematodes.}

The rhizophores are fibre-like, 6 to 10 millimetres in length and $\frac{1}{4}$ to $\frac{1}{3}$ millimetre in diameter. They only develop towards the base of the stem and never higher up. The epidermis, hypodermis, and cortex cells do not differ much from one another in size. The epidermis has a very thin cuticle, and with those of the hypodermis shows but slightly secondary walls, probably because they are formed very close to the moist soil. The cortex is composed of four to seven rows of cells. The vascular bundle is small, 
and its xylem is but little developed, being composed of seven tracheides, of which four belong to the protoxylem.

The roots are very thin; only a few cells of the epidermis are elongated into hair-roots. Then follow two layers of thin-walled cells, then the hypodermis cells composed of three layers which are but very slightly thickwalled. The vascular bundle is very small-the writer counted from two to three sieve-tubes in the phloem and but four to five tracheides in the xylem.

\section{Selaginella decora.}

The rhizophores have a length of 30 to 45 millimetres and a diameter of $\frac{3}{4}$ to I millimetre. The cells of the epidermis are much smaller than those of the hypodermis; the cell-walls of both are thick. The cortex is composed of 10 to 15 rows of cells. In comparison with the thickness of the acrial root, the vascular bundle is not as well developed as in other species. The protoxylem is composed of three to four tracheides and the metaxylem also of three to four. The phloem is, in comparison, better developed. The construction of the very thin roots is very much like that of the previous species.

\section{Selaginella Douglasi.}

The length of the rhizophores varies from 20 to about 28 millimetres; its diameter from $\frac{1}{3}$ to $\frac{1}{2}$ millimetre. The cells of epidermis, hypodermis, and mostly those of the cortex, are very thick-walled in plants which were developed in their native country (Oregon State, U.S.A.), where they have the habit of xerophytes growing upon stems of trees. Individuals which were grown in moist soil, and in the damp environment of a greenhouse, show considerably less thickened walls in the above-mentioned tissues. The xylem is well developed, and is composed of about five tracheides belonging to the protoxylem, and ten to sixteen belonging to the metaxylem. The phloem which surrounds the xylem is much like that of the stem.

\section{Selaginella molliceps.}

This species forms strong well-developed rhizophores, especially when twigs are growing close to one another. They attain a length of 6 to 15 millimetres and a diameter of $\frac{1}{3}$ to $\frac{1}{2}$ millimetre. The epidermis is composed of rather large cells, although somewhat smaller than those of the cortex. The cuticle is thin, even that of older rhizophores. The terrestrial root does not show marked differences, except that as usual the epidermis is followed by two thin-walled layers of cells. The development of the vascular bundle is like that of $S$. decora.

\section{Selaginella Bakeriana.}

The rhizophores somewhat resemble in anatomical construction that of S. rubella. They reach a length of 6 to 12 millimetres and a diameter of $\frac{1}{3}$ to $\frac{1}{2}$ millimetre. The cells of the epidermis and hypodermis remain 
thin-walled for a long time, only being thick in the older rhizophores and in two or three layers of the outer cortex (Fig. V, 1 and 2). The secondary layers in the walls of younger rhizophores are not formed as soon as those in several other species. The vascular bundle is like that of S. rubella; there are, however, not as many tracheides in the metaxylem.

The terrestrial root has, with the exception of the epidermis and the two following rows of cells, which are large, the same construction as the stem. The cells of the hypodermis are slightly thick-walled.

\section{Selaginella viticulosa.}

This species develops aerial roots very close to the base of the stem; they attain a length of 3 to 8 millimetres and a diameter of $\frac{1}{4}$ to $\frac{1}{3}$ millimetre ; consequently very little is exposed to the air.

The cells of the epidermis, hypodermis, and cortex are almost of the same size, and those of the first two tissues are thick-walled when they become older. The epidermis has no developed cuticle. All the walls of the epidermis and hypodermis are encrusted with a red pigment; the walls of the cortex cells are colourless. The cortex is composed of eight to ten rows of cells. The vascular bundle is comparatively little developed; its xylem is composed of three to four tracheides belonging to the protoxylem and four to five wide ones belonging to the metaxylem.

Of the terrestrial root, which shows very much the same characteristics, it may be mentioned that there also the hypodermis is red-coloured for some length, but this colour disappears when the roots penetrate deeper into the soil.

\section{Selaginella serpens.}

The aerial roots attain a length of 6 to $\mathrm{x} 2$ millimetres and a diameter of $\frac{1}{4}$ to $\frac{1}{3}$ millimetre. The epidermis and hypodermis are composed of cells whose walls are slightly thickened; the cortex is composed of three to five layers of thin-walled cells. The endodermis and pericycle are composed of small cells which are frequently difficult to distinguish from those of the outer cortex. The xylem is composed of only seven to eight tracheides, of which two to three belong to the protoxylem.

The terrestrial roots (Fig. $\mathrm{X}$ ) are very thin; the epidermis and the two following rows of cells are rather large; root-hairs are formed abundantly and are relatively long; the hypodermis is composed of about three rows of cells, which contain some secondary walls; the cortex is formed by about three to four cell-layers, of which all the cells are much smaller than those of the hypodermis, and especially those of the epidermis. The vascular bundle is in all instances very small; it is composed of a few sieve-tubes; the xylem is formed by, as a rule, only three tracheides, which seem to belong to the protoxylem. 
Selaginella formosa.

The aerial roots have a length of 40 to 60 millimetres and a diameter of $\frac{1}{2}$ to $\frac{3}{4}$ millimetre. The epidermis is relatively large-celled, also the hypodermis. The cuticle is well pronounced; the cells of the hypodermis ate not as thick as is the case with other species. The cells of the cortex are composed of seven to eight rows of cells and are larger than those of the

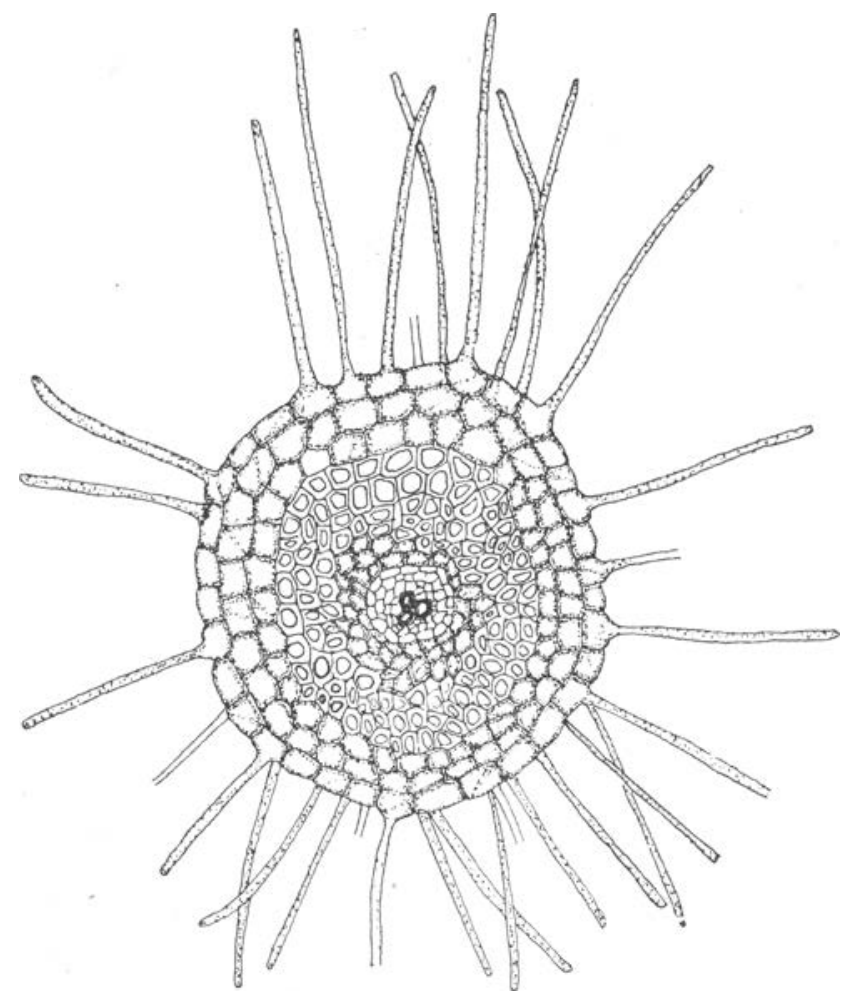

FIG. X. Section of root of $S$. serpens.

hypodermis. The endodermis, as a rule, can be well distinguished from the other tissues. The xylem possesses eight tracheides in the protoxylem and five to eight tracheides in the metaxylem.

The terrestrial roots show, with the exception of the first three celllayers, the same anatomical construction as that of the rhizophore; although the cortex is not composed of as many layers of cells, the hypodermis on the other hand remains the same. The vascular bundle is almost the same: there are only a few tracheides less.

\section{Selaginella apus.}

The rhizophore is very thin and fibre-like; its length amounts to 5 to 12 millimetres and its diameter $\frac{1}{4}$ to $\frac{1}{3}$ millimetre. The cells of the 
epidermis and hypodermis are very large, almost as large as those of the cortex cells. Cells of the epidermis and hypodermis only contain slightly secondary layers. The vascular bundle is small, although its elements are all represented; the xylem is only composed of five to six tracheides, of which two to three belong to the protoxylem. There is little difference in the construction of terrestrial roots.

\section{Selaginella Galeotti.}

The rhizophores attain a length of 80 to 120 millimetres and a diameter of $\frac{1}{2}$ to $\frac{3}{4}$ millimetre. The epidermis cells are small; those of the hypodermis are much larger and as big as those of the cortex. The cellwalls of epidermis are very thick; very little space has been left in those of the older rhizophores. In many cells of the cortex a red pigment is developed in the vacuoles, or at least those which developed towards the side of the approaching light. The cortex is formed by twelve to twenty layers of cells. The vascular bundle, especially the xylem, is not as much developed as one would expect; there are four to five tracheides in the protoxylem and about five in the metaxylem. The terrestrial root, which is much thinner than the aerial root, has a less developed cortex, which is formed by three to four layers of cells; although otherwise it shows much the same development as the aerial root.

\section{Selaginella patula.}

The aerial root reaches a length of Io to 18 millimetres and a diameter of $\frac{1}{2}$ to $\frac{3}{4}$ millimetre. The cells of the epidermis, hypodermis, and cortex are practically of the same size; only those of the inner cortex are larger. The cuticle is very little pronounced, although the other walls of the epidermis and those of the hypodermis are furnished with secondary layers. The vascular bundle does not differ much from that of $S$. molliceps. The terrestrial root also does not show much difference, except that part which is directly in touch with the soil.

\section{Selaginella Martensi.}

The rhizophore becomes 30 to 60 millimetres in length and $\frac{3}{4}$ to 1 millimetre in diameter. The epidermis has a thick cuticle on plants which have been rather exposed, and as thin as an ordinary primary wall when developed in a shady and very moist environment. The other walls of the epidermis and those of the hypodermis are thickened in the same degree. The cortex is composed of twelve to fifteen usually thin-walled rows of cells. Towards the vascular bundle they become smaller. The endodermis and pericycle are very distinct. The elements of the phloem are well represented and hardly differ from those of a stem. The xylem is formed by four to five vessels of the protoxylem and ten to fourteen belonging to the metaxylem. 
The terrestrial root has a large-celled epidermis, which forms relatively long root-hairs; it is followed by two other thin-walled layers, whose cells are of the same size ; this tissue is succeeded by three rows of cells belonging to the hypodermis, which as usual are thick-walled. There is no difference in the vascular bundle in comparison with that of the aerial root, only that its elements are relatively fewer the thinner the root in the soil becomes.

\section{Selaginella atrovirens.}

The rhizophore has a length of 35 to 65 millimetres and a diameter of $\frac{3}{4}$ to I millimetre. All the cells of the epidermis, hypodermis, and sometimes of the outer cortex are furnished with secondary walls, although these are not very thick. The cortex is composed of eight to twelve rows of cells, which are larger than the hypodermis cells. The vascular bundle is as a rule surrounded by a distinct endodermis and pericycle. The xylem takes considerable room in the vascular bundle, and is more developed than the phloem. The metaxylem is composed of twenty to twenty-eight tracheides; the protoxylem sometimes contains eight to fifteen of such vessels, and is strongly developed in the primary rhizophore.

The terrestrial roots are thicker than those of most other species, and attain a thickness of $\frac{1}{2}$ to $\frac{3}{4}$ millimetre. The root-hairs are not very abundant. The epidermis, as a rule, is succeeded by two other thin-walled layers; the hypodermis is composed of cells which are of rather considerable thickness, especially in those which grow close to the surface; those which have developed considerably deeper in the ground are in possession of a hypodermis which has not as many secondary layers in its walls.

\section{Selaginella grandis.}

The aerial root reaches a length of 8 to 12 millimetres; in one instance I found one of 25 millimetres; its diameter varies from $\frac{1}{2}$ to I millimetre. There are two different types of rhizophores, one of which has developed a root-cap and root-hairs; the other has no root-hairs and no root-cap. The primary rhizophore, which is in direct connexion with the stem, very rarely develops root-hairs, and never a root-cap, as far as I was able to observe. While the rhizophore with root-cap develops all its epidermis cells into root-hairs, the other one without root-cap occasionally forms a root-hair from an epidermis cell, leaving the other cells of epidermis to their normal development.

The aerial root without root-cap is composed of small cells; those of the epidermis, hypodermis, and cortex are of the same size. The two former tissues are thick-walled; the cortex is composed of ten to fifteen rows of cells. The vascular bundle is very small, although it is very strongly developed in the stem. The endodermis cannot be clearly distin- 
guished from the small cells of the inner cortex. The xylem is composed of six to nine tracheides; those of the protoxylem are very narrow. Aerial roots which are developed in a very moist environment always develop roothairs and root-cap. As has been stated, every epidermis cell changes into a root-hair ; these hairs are narrow and long. The epidermis is followed by only one thin-celled layer, which is succeeded by a thick-walled hypodermis. There are less rows of cells forming the cortex than in a root without roothairs (Fig. III, 3 to 9).

Terrestrial roots are the same as the latter kind of roots.

\section{Selaginella cuspidata.}

Rhizophores are only developed towards the base of the stem, and only when growing in a very damp environment; plants which grow in their

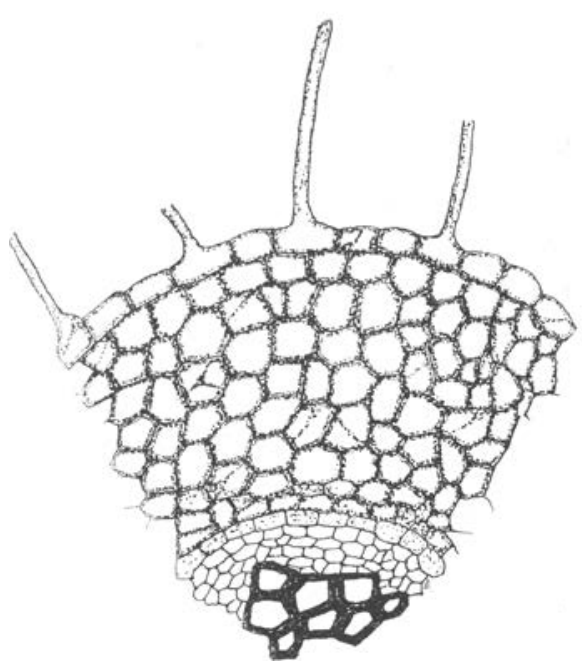

FIG. XI. Section of root of S. Bakeriana.

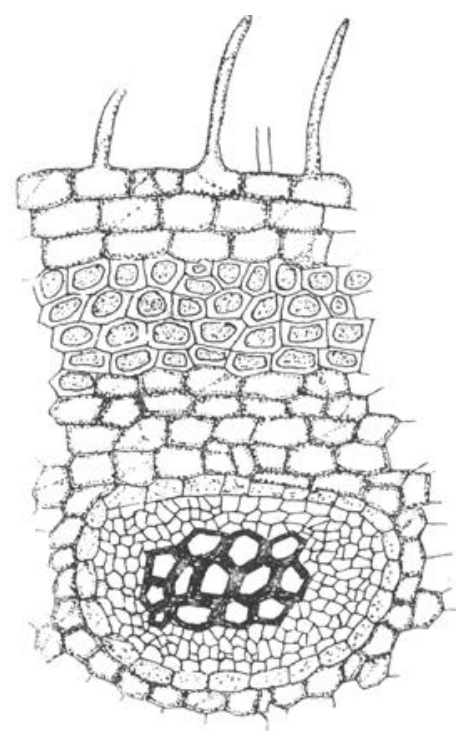

FIG, XII. Cross-section of root of S. rupestris.

native environment do not develop such roots, which is also the case with other. xerophytic species, e.g. S. pilifera and S. lepidophylla. They attain a length of 5 to 8 millimetres and a diameter of $I$ to $I \frac{1}{2}$ millimetres. These are very tough and velvety; the former quality is caused by its welldeveloped sclerenchyma, the latter by the presence of innumerable roothairs. The writer vas not able to observe aerial roots without roothairs.

A section of the root (Fig. XIII, I and 2) shows the following: the epidermic cells are all transformed into root-hairs, after which follows one layer of thin-walled cells; this tissue is followed by layers of hypodermic and cortex cells, which are composed of eight to nine rows of cells. These are succeeded by six to eight rows of thin-walled cortex cells; 
those approaching the vascular bundle are considerably smaller, which makes the endodermis less clearly visible. The phloem as well as the xylem

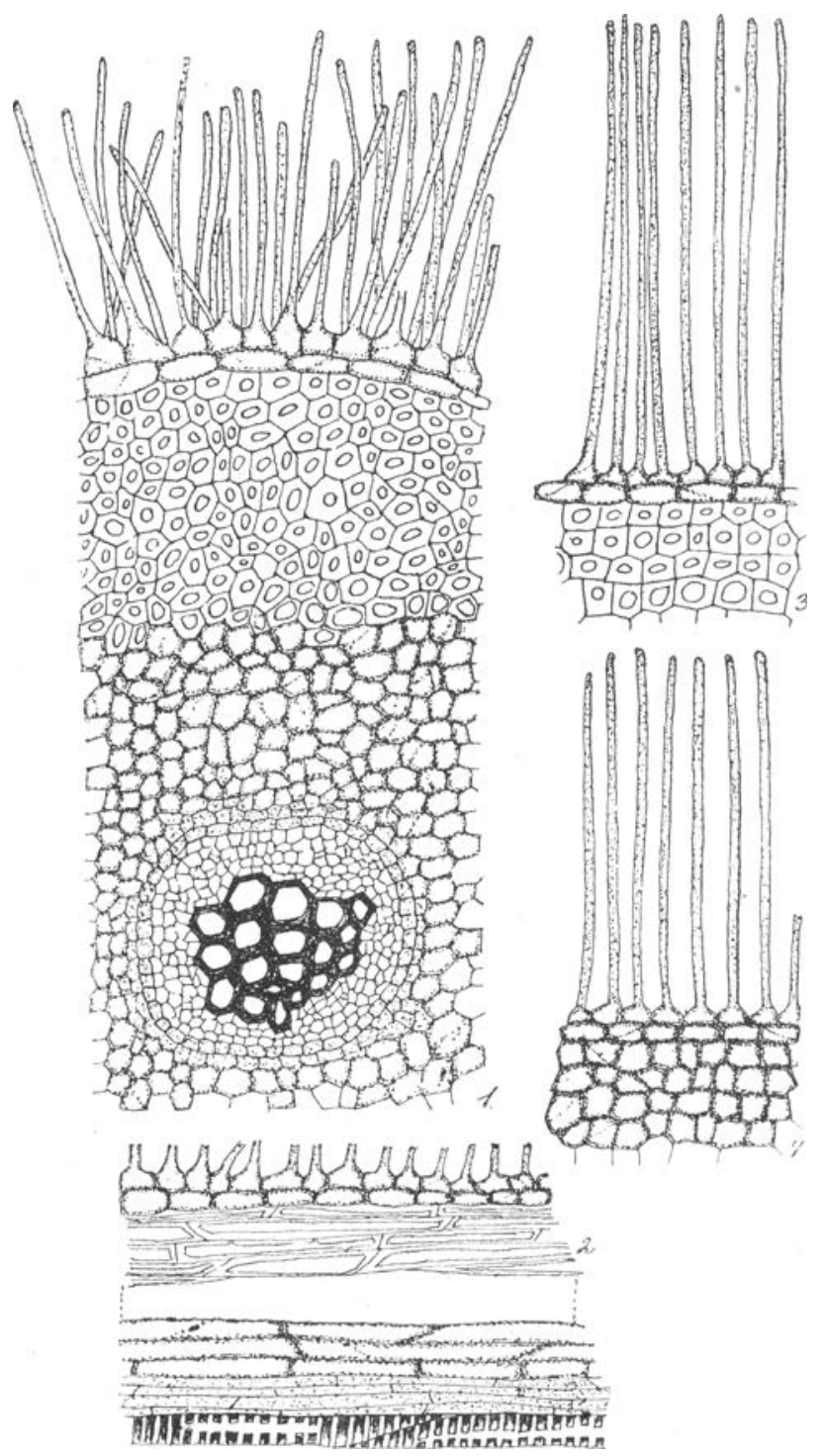

FIG. XIII. I, 2, S. cuspidata: I, cross-section of aerial root; 2, longitudinal section of same. $3,4, S$. pilifera: 3 , old thizophore; 4 , young rhizophore.

is well developed. The protoxylem is composed of about five tracheides ; the metaxylem of ten to fourteen.

The terrestrial roots are exactly like the former. Roots which are developed in a semi-arid desert region have as a rule a cortex which is M $\mathrm{m} 2$ 
almost entirely thick-walled, with the exception of two or three rows of cells towards the endodermis.

Roots of $S$. pilifera and $S$. lepidophylla are very much the same; only the root-hairs are longer.

Selaginella rupestris.

The length of the aerial roots is 4 to 8 millimetres, and the thickness $\frac{1}{4}$ to $\frac{1}{3}$, sometimes $\frac{1}{2}$, millimetre. The epidermis is thick-walled and furnished with a clear cuticle; the hypodermis also is composed of thick walls. The cortex is formed by six to eight rows of thin cells in plants which were developed in a moist environment, but are thick-walled in plants which were grown on exposed rocks. There is no difference in construction of the vascular bundle between that of a root and of a stem, which applies to all species of the homophyllous Selaginellas, e.g. S. rupincola, S. densa, $S$. capensis, and other species, a fact which is also to be noticed in the case of the root and stem of Lycopodium.

The terrestrial root shows a large and thin-celled epidermis, which forms short and rather wide root-hairs. These are succeeded by two rows of thin-walled cells of the same size; after which a hypodermis is to be noticed attaining a thickness of three or four rows of cells. The cortex is usually composed of four rows of cells. The vascular bundle is of the same type as that of the aerial root and stem (Fig. XII).

\section{SUMMARY.}

The species of Selaginella are remnants of older periods in which also other related genera reached their highest pitch of development. They belong to the primitive vascular plants, and therefore morphologically are of much importance as far as the origin of the plant organs is concerned.

Some of the present living allies of Selaginella are in possession of true roots, although anatomically these do not differ very much from that of the stem (e. g. Lycopodium); some do not have true roots, such as species of the Psilotaceae.

Generally the root is simple in construction and differs from the stem, the former lacking the lacunae and trabeculae of the latter.

There is no important anatomical difference between aerial and terrestrial roots. The difference of the outer tissue is due to environmental circumstances.

Physiologically both kinds of roots have the same characteristics in the same degree; both are negative heliotropic.

Roots with root-cap always have root-hairs, those without root-cap very rarely have root-hairs.

Of all species, the root originates with regard to the stem exogenously; they branch monopodially. 
Some species form, when bruised, small stems instead of rhizophores; these suggested to many investigators that the latter are leafless stems. The anatomy shows that these branches have the same construction as a stem and are positive heliotropic, whereas the so-called rhizophores have the construction of a root and are negative heliotropic.

The vascular system is monarch; the endodermis and pericycle are always present. The phloem shows the same arrangements as in the stem, although its elements are less abundant. The xylem is composed of one group of protoxylem and usually a well-developed metaxylem.

The thick-walled tissue which follows the three layers of thin-walled cells of the periphery of the terrestrial roots apparently belongs to the hypodermis.

\section{BIBLIOGRAPHY.}

1. Bower, F. O.: The Origin of a Land Flora. London, $19 \circ 5$.

2. Bruchmann, H.: Von den Wurzelträgern der Selaginella Kraussiana. Flora, xcv. I50-66, 1905 .

3. Campbeld, D. H.: Structure and Development of Mosses and Ferns. New York, 1905.

4. Engler and Prantl: Die natïrlichen Pflanzenfamilien, i. 62 I, 1900.

5. Frits, R. E. : Et Bidrag til kännedomen om Selaginella-Rotbararna. Svensk bot. tidskr., v. $252, \mathrm{Ig} \mathrm{I} 2$.

6. Goebel, Karl: Organographie der Pflanzen, 2. Ansg. Jena, 19r3.

7. — : Einleitung in die experimentelle Morphologie der Pflanzen. Leipzig, 1908.

8. Nägeli, C., and Leitgeb, H.: Eutstehung und Wachstum der Wurzeln. Beitr. wiss. Bot, pp. $73^{-160, \text { r } 868 .}$

9. Pfeffer, W. : Die Entwicklung des Keimes der Gattung Selaginella, Hanst. Abh. i. I-8o, I 87 I.

10. Sarauw, Geo. F. L.: Versuche über die Verzweigungsbedingungen der Stutzwurzeln von Selaginella. Ber. der Dentschen Bot. Ges., ix. 5I-65, $189 \mathrm{I}$.

11. Scorr, D. H.: Studies in Fossil Botany. London, I9o9.

12. Tieghem, Ph. van : 'Traité botanique, $2^{\circ}$ éd. Paris, I 892 .

13. - - and Dovliot: Recherches comparatives str l'origine des membres endogènes dans les plantes vasculaires. Ann. d. sc. naturelles, Bot., viii, I 888 .

14. Treub, M. : Recherches sur les organes de la végétation de $S$. Martensii. Musée bot. de Leide, ii, 1877 .

15. WaAge, Th, : Über haubenlose Wurzeln der Hippocastanaceen und Sapindaceen. Ber. der Deutschen Bot. Ges., ix. I 32-62, I89I.

16. Warming, Eug.: Om Rodderne hos Neottia nidus avis. Videnskab. Medd. fra nat. Forening for $187 \%$, pp. 26-32.

17. Worsdel,L, W. C.: The Rhizophore of Selaginella. New Phytologist, ix, igro. 